\title{
The Difference between Male and Female Language Style of Students at FKIP UHN Pematang Siantar
}

\author{
Christian Neni Purba, s.Pd., M.Hum.
}

\author{
English Department, Nommensen HKBP University, Indonesia
}

\begin{abstract}
This research studies the difference between male and female language style of students at FKIP UHN Pematangsiantar. This research focused on what language style are used by male and students of at FKIP UHN Pematangsiantar the differences of male and female students language style at FKIP UHN Pemtangsiantar. This research applies descriptive qualitative research, aimed at describing language style of eight grade students at FKIP UHN Pematangsiantar. The subject of this study are 10 students, consists of 5 male students and 5 female students. The data were collected through recording and observation. The method covers research design, the subject, the object, the instrument, the technique of collecting data and the technique of analyzing data. The result of this research shows that there are two language style that used by male students, three language styles used by female students. The difference language style between male and female students found that intimate style used by female students but male students didn't used intimate language style. Finally, from the result of the data analysis, the writer found that every students have different language style. Male and female students at FKIP UHN Pematangsiantar used three types of language style from five language style. Formal and casual style used by male students and formal, casual and intimate style used by female students.
\end{abstract}

Keywords - Casual, Consultative, Formal, Language Style, Intimate, Sociolinguistic, Utterance.

\section{INTRODUCTION}

A language is a dynamic set of visual, audiotory, or tactile symbols of communication and the elements used to manipulate them. Language is considered to be an exclusively human mode of communication. No one speaks the same way all the time; instead they speak for a wide variety of purpose. Sapir (1921:8) states "Language is a purely human and non instinctive method of communicating ideas, emotions and desires by means of system of voluntarily produced symbols." From that statement, it is known that language has the crucial role and a vital role in human life and also many profits can get in various aspects of human life. By language, people are able to interact and communicate one another for whatever they do.We can find that they use formal language but when finished learn, they use informal language when they want to talk about anything in out of the classroom with their friends like bonyok (parents), awak (I), lo (you),woii (guys), coy (call name of friend), kool (handsome), jutek (annoyed), katrok (rube), gendeng (noisy), rempong (busy), lol (laugh out loud), kemek (food), meneketehek ( I don't know), longor (full) etc. It means that we have find out the different language style in the different context and situation. So a speaker must to adjust to the situation where they communicate. the writer will analyzed the five language styles, based on frozen, formal, consultative, casual, and intimate style found in the conversation of students of FKIP UHN Pematangsiantar at English Morphology Class. We have known the styles of language are parts of language variation that are used for specific purpose.

\section{The Problems of the Research}

Based on the background of the research, the problem in this research are formulated on the following:

1. What language style are used by male students of FKIP UHN Pematangsiantar?

2. What language styles are used by female students of FKIP UHN Pematangsiantar?

3. What are the differences of male and female students' language style at FKIP UHN Pematangsiantar?

\section{REVIEW OF LITERATURE}

The Meaning of Language

As a social element, human have to be able to communicate by language. It relate to the human which 
have the relationship to do interaction with others in building communication that can understand each other. There are some defenitions about language that can be understand which is supported from some authors. Varshney (2003:1) says "Language is a very complex human phenomenon; all attempts to define it have proved inadequate." It means that there are some chronically explanations to define about language in human life.

\section{Language Variation}

Language variation generally forms part of sociolinguistic study. It is connected to the varied linguistic of sociocultural meanings which in a sense, occurrence of everyday social interactions, relative particular cultures, societies, social group, speech communities, languages dialects, varieties, style. Hudson (1980:24) defines "a variety of language as a set of linguistic items with similar social distribution", it means about the elements of veried language are placed like valuable thing to people based on supplying something in social system which are similar.

They are widespreaded in this world such as French, English, London English, Indonesian, the language or languages used by a particular person. Language can vary from one individual to the next and from region, village, family which are called speech community. The variations can be found in the same community from people of different age, sex, social classes, occupations, or cultural group by their speech. Moreover, language variation can be caused by some factors. It will be explained briefly according to Varshney (2003:296) as follows;

- Nature of participants, their relationship (sexual, occupational, etc).

- Number of participants (two face-to-face, one addressing a large audience, etc).

- Role of participants (teacher/student priest/father/son/husband/wife,etc).

- Function of speech event (persuasion, request for information ritual, verbal, etc).

- Nature of medium (speech, writing, scripted speech, etc).

- Genere of discourse (scientific, experiment, sport, art, religion, etc).

- Physical sending (noisy, quiet,public, private, family, formal gathering, familiar-unfamiliar, appropriate for speech (in sitting room) (inappropriate).

- Regional or geographical setting, etc.

Chaika (1982: 29) stated language style is the way people manipulate others and control their interaction in bringing massages, idea, or mind conveyed in word or tone of voice.
Social styles (including dialect styles) are a resource for people to make many different sorts of personal and interpersonal meaning.

In communication, language style can be found tin he word and grammar which are choosed and used.For instance, In relax situation, may be talking with friends, people may use a casual words and grammar in order to make a friendly situation.Language has potentiality for making communication successful and establishing social togetherness if it is use well, if not it will be a handicupfor succesful communication and interection. It is important to pay attention to certain aspect of variation of language style to achive successful communication fluently. Good language must have 3 elements, those are: honesty, respect, and good manner.

According to Keraf (198:99) states that Style is actually a part of a word choice question the suitability of the word, phrase, or clause particular, to deal with certain situations. Because it is a style issue taht encompasses all linguistic hierarchy: individual choice of words, phrases, clauses, and sentences or include also a discourse as a whole. Even tone that implied behind a discourse, including the question of style. So the range of style is actually very broad, covering not only the sentence elements that show the particular pattern, such as that commonly found in classical rhetoric. Style is actually none other than the way of expressing yourself, whether through language, behaviour, dress and so on. In term of language, style allows to as sess the personal, character and ability of person who uses that language.

Style describes the interection is formal or informal and the interpretation of massages or how to take what is being said whether seriously, ironically, humorously, dubiously or in some other way. From those definition, the writer concludes that language style is the way people use the language in the most effective way in communication, whether in written or spoken language. it can be found in choosing of the word and grammar and sentence structures.

\section{The Research Design}

\section{RESEACH METHODOLOGY}

The type of the research in this thesis is descriptive qualitative research. According to Maleong (2006:6) "Qualitative research is research that aims to understand the phenomenon of what is experienced research subjects, such as behavior, perception, motivation, or action, etc". In other words qualitative research as research procedures which produce descriptive data is in the form of language or words written or spoken of the public and 
observable behavior. Qualitative research also concerns with interpretation of meaning of social interaction. The writer wants to know the difference between male and female language style of students.

\section{The Subject and object of the Research}

The subject of this research were the students who learning English Morphology class, there were 30 students of English Department, FKIP UHN PematangsiantarThe object of research was the conversation of male and female students language style in English Morphology class at FKIP UHN Pematangsiantar.

\section{FINDING AND DISCUSSION}

The Analysis of the Data

Data 1:

Context : The conversation was taken from Male students on April 2018 at 07.30- 09.10.00 and $10.00-11.40$ am in the classroom (room A2 and A3)

\author{
Male Students Utterances \\ Data \\ Male 1 : apa kata Mam it? \\ Male 2 : katanya 'siapa yang tau defenisi 'free \\ morfem'. (1) \\ Male1 : apa? 'Free morfem'? \\ Male 2 : kalok tau kau jawablah. \\ Male1 : gak berani ak, belum lepel-lepelku \\ soal kayak gitu. (2)

$\begin{array}{ll}\text { Data } & \\ \text { Male } 3 & \text { : da siap kau tugas 'affix'? } \\ \text { Male } 4 & \text { : uda...kau? } \\ \text { Male } 3 & \text { : gampangnya. ya siaplah. } \\ \text { Male } 4 & \text { : banyak x ceritamu. } \\ \text { Male } 5 & \text { : uda dibelikkan kakaku paket, } \\ \text { aturannnya } & \text { gk siap. (3) } \\ \text { Data } & \\ \text { Male } 1 & \text { : berapa uang fotocopy kertas yang } \\ \text { dari Miss it? (4) } & \\ \text { Male } 2 & \text { : dua ribu lima ratus. } \\ \text { Male } 1 & \text { : sama si X dikasikan? (5) } \\ \text { Male } 2 & \text { : ia. }\end{array}$

Data Analysis (1):

The example (1) from data (1) "Katanya "siapa yang tau defenisi "free morfem" it means that the student repeat his lecturer question. In the sentence, the word of "tau" means 'mengetahui' (know). So, the student used the casual style because the word of tau is the example of casual style. (2) "Gak berani aku, belum lepel-lepelku soal kayak gitu". The meaning of the sentence was that the male student didn't know to answer his lecturer's question that was why he was not ready to be asked. The word of gak means tidak (not) and lepel is tipe (type). So, the student used the casual style because he use the slang word. (3) "Uda dibelikan kakakku paket, aturannya gak siap" It means that he wanted to buy something. The word of "aturannya" means seharusnya (should) and the word is casual style because the word is not complete in grammar.

(5) Sama si X kasikan. This sentence means the speaker suggest his friend to give the money to $\mathrm{X}$ (classroom treasure). The word of 'kasi' means 'berikan or serahkan' (give). So, It is concluded that it is casual style.

(4) Berapa uang fotocopy kertas yang dari Miss itu?. This is a casual style because the word 'uang' it should be 'biaya' (cost)

Data 2:

Female Students Utterances

Context : The conversations were recorded from Female students on April 2018 at 09.30 am. I was happened in the English Morphology classroom, A2 and A3 rooms.

Data Analysis (2):

Data

Female 1 : Cepatlah...sini masih kosong

Female 2 : kosong?

Female $1 \quad$ : Ia. Mana si Y? (15)

Female 2 : Pindah sini X? Sinilah Y, sayang (16)

Female $1 \quad$ : Sttttts, pray kita.

Data

Female 3 : Y, jelek kali kau hari ni?

Female 4 : ishhh, cantik $x$ aku ya, $X$ ? (17)

Female 3 : Udalah...open chapter 3 kata Miss it!

Female 4 : Tentang "root, affixes and their shapes", dah aku baca di rumah tapi masih bingung aku.

Female 5 : Wei, dengarlah Mam it jelaskan! (18)

From the data above male student said (15) "Mana si Y?" It means that the female students expressed the strong question which was about where their friend, Y (initial name of student). It is casual style which 
can bee seen from the word such as "mana" is a casual word which becomes "dimana" (where). Example (16)

Pindah sini, X? Sinilah Y, sayang. (17) "Ish, cantik kali kau ya, X!". The female student expressed the strong opinion about her friend appearance, $\mathrm{X}$ (initial name of student). It is casual style that can bee seen from a little particle such 'Ish' that means kagum (amazed or wonder). It becomes as pressuring to symbolize of casuality. Then,the word such as "kali" is as a casual word which becomes "sangat"(very) so the sentence is casual style. This is the (refers to his friends who was talking while their lecturer was explaining the material in front of the class. She was not unly used 'wei' but also 'jelaskan' 'menjelaskan or menerangkan (explaining).

(18) Wei, dengarlah Mam itu jelaskan! It means that the female student asked her friends for paying attention to their lecturer explanation. The second one, she asked her friends who brought a dictionary. There is a casual word such as "wei" "woi" which becomes "kau"(you). It is clear that the sentence is casual style because the slang word.

After analyzing the data, the writer found some findings about the difference between male and female Language Style of Students. Based on the data analysis, the writer found that two language styles that used by male students. They are: Formal style and casual style. Formal style is used for important or serious situation, the words it's complete sentences and specific word usage. Formal style of male is $5.8 \%$ Formal style of female is $7.2 \%$ Casual style of male is $40.6 \%$ Casual style of female is $27.5 \%$ Intimate style of female students is $18.8 \%$.

Formal style is used for important or serious situation, the words it's complete sentences and specific word usage. For examples: Jadi siapakah diantara kalian yang benar, Mam, Mam, saya mau bertanya boleh, Mam, Mam, bolehkah saya menjawab, Mam?, Dimana basenya ini?, etc. And casual style is used for the conversation in our relaxed or normal situation and often full of slang. For examples: Gak berani aku, belum lepel-lepelku soal kayak gitu, Aturannya ambil kertasnya satu samaku, Ehh, si loakloak on, Ditutup ginikan?, etc.

The result of this research from the data analysis is to answer of second research problem. Base on the data analysis, the writer has analyzed five types language style that use by female students. The writer found three languages style that used by female students. They are formal style, casual style and intimate style. Formal style is used for important or serious situation, the words it's complete sentences and specific word usage. For examples : J, sudah selesai?, “Apa kabar?” Berapa nilaimu?, Sepatu sipakah ini? etc. Casual style is used for the conversation in our relaxed or normal situation and often full of slang. For example:"Klen pikir sudah cantik, klen!”, "Klen pikir sudah cantik kalian?", Dia gk ada langganannya. "Aku deg-degkan kalau rendah", Disuruh mam itu kayak gitu” etc. Intimate style is a completely private language developed within families, lovers and the close of friends and generally signal intimacy. For examples :"Beb, beb berapa kau beli? Kotor beb coret-coret. Beb, berapanya morfem ni?, Fotocopian dari Mis Christian kau bawa, Nang? "Bantu aku, Nang?" etc. There are 37 utterances found by the writer as long she analyzed based on the duration from 3 data. There are 5 utterances of formal style (7.2\%). Casual Style are 13 utterances (27.5\%) and 13 utterances categorized into intimate style $(27.5 \%)$.

\section{CONCLUSION}

Based on the data analysis on conversation of male and female students, the writer concludes:

1. From the investigation of the finding to answer the first research problem, the writer found that Male students at English Morphology used two types of language style. They are formal style and casual style from 6 data that the writer analyzed. There are 32 utterances. Four are formal style (5.8\%), twenty-eight are Casual Style (40.6\%). The data of female styles are 37 utterances. Formal Style is five utterances (7.2\%), Casual style are 19 utterances $(27.5 \%)$. Intimate style is found for female students, there are 13 utterances (18.8\%). Frozen and consultative style was not used by the students. Consultative style is variety appropriate in discussion while intimate style is also used a completely private language developed within families, lovers and the close of friends.

2. From the investigation of the finding to answer the third research problem, the writer found that the differences between male and female students state on intimate style because female students used intimate style in daily conversation, but male students didn't used in conversation because every students have difference character in spoken language in each style of their language as an interested for them such as female students. They used their intimate style to change the name of their friends into nicknames their friends as signal intimacy.

3. There are similarities in the characteristics of male and female students that is they use formal and casual style. 
4. The writer to contribute for the students to choose which language style that they like, such as casual style.

\section{REFERENCES}

[1] Arikunto, Suharsimi. 2013. Prosedure Penelitian Suatu Pendekatan Praktik. Jakarta: PT Rineka Cipta.

[2] Chaika, Elaine. 1982. Language the Society Mirror. Rowley Massachusetts: New House Publisher Inc

[3] Gleason, H.A. 1965. Linguistic and English Grammar. New York: Holt, Rinehart and Winston.

[4] Heaton, J.B. 1988. Writing English Learning Test. United Kingdom: Longman Group.

[5] Hudson, R.A. 1980. Sociolinguistic, New York: Cambridge University Press.

[6] Joos. (in Broderick 1976). The five clocks of Martin Joos: Why they keep on ticking. Old Dominion University.

[7] Keraf, Gorys. 1981. Diksi dan Gaya Bahasa, Jakarta: PT Gramedia Pustaka Utama.

[8] Leech and Short. 2006. Women's language style. Akron: Ohio: L \& S Books.

[9] Maleong, Lexy J. 2006. Metodologi Penelitian Qualitaitve, Bandung: PT Remaja Rosdakarya.

[10] Nurul. 2011. The Different Language Style and Language Function Between Students and Teachers. Malang.

[11] Sandra and Nancy. 1996. Sociolinguistics and Language Teaching. Cambridge: Cambridge University Press.

[12] Sapir, Edward. 1921. Language an Introduction to the Study of Speech. Copyright by Harcourt, Brace \& World, INC. 